\title{
INSTITUTIONAL DESIGN ISSUES AND POLICY CHALLENGES: REFLECTIONS FROM FORMER CHAIR OF THE COMMERCE COMMISSION, DR MARK BERRY
}

Dr Mark Berry*

I was asked by the Law and Economics Association of New Zealand to reflect tonight on my time as Chairman of the Commerce Commission (NZCC). I expect that the conference organisers may have wished that I revisited some of the key decisions during my ten year tenure. However, I fear that a retrospective of such cases would be dated, provide no new insights and would most likely be excruciatingly boring for this audience.

I would like instead to address two contemporary topics tonight. The first relates to institutional design issues facing the NZCC, and indeed all competition authorities. In particular, I will comment on the vexed issue of the role of the "board" of such institutions. The second topic relates to a central policy issue which arises as a result of the Court of Appeal's observations on the total welfare standard in the NZME Ltd $v$ Commerce Commission (NZME/Fairfax) merger decision. ${ }^{1}$ This decision may potentially have a far-reaching impact not only on the authorisation process under the Commerce Act 1986 (the Act), ${ }^{2}$ but also on the goals which underpin this legislation.

* Barrister, Auckland. Dr Berry was Chairman of the Commerce Commission from 2009-2019. This speech was delivered to the Law and Economics Association of New Zealand in Auckland on 10 March 2020, and in Wellington on 11 March 2020. Comments and questions are welcome to mark.berry@ mblaw.co.nz.

1 NZME Ltd v Commerce Commission [2018] NZCA 389, [2018] 3 NZLR 715 [NZME/Fairfax].

2 Mergers and restrictive trade practices involving market power concerns may be authorised on countervailing "public benefit" grounds: Commerce Act 1986, ss 58 and 67. In assessing the "public benefit", s 3A of the Act requires that regard must be had to any efficiencies that may be likely to result. The concept of "public benefit" can also extend to non-economic considerations: NZME/Fairfax, above n 1, at [54]-[81]. 


\section{INSTITUTIONAL DESIGN}

In my past life, I was repeatedly exposed to the perils of select committee hearings. Endless hours were spent preparing for these hearings. Almost invariably we were blind sided, often on the first question.

Such an experience occurred on one occasion when an opposition Labour MP put to me a question along the following lines: "Surely you must be embarrassed that there is no proper accountability for your decisions given that there is no independent board oversight of your work, as happens with most other competition authorities around the world." This question took me somewhat by surprise at the time, given that it came not long after we had endured the extensive merits review proceedings in the High Court against the NZCC's input methodologies decisions relating to the regulated utilities. ${ }^{3}$

As I recall, I assured the Select Committee that we felt accountable for reasons such as the following:

- When you are writing decisions that are potentially subject to appeal, you are acutely aware that this form of judicial scrutiny (and accountability) is likely to be extreme.

- A further layer of judicial oversight (and accountability) applies to cases prosecuted by the NZCC. The requirement to satisfy the court that a case is provable in this setting imposes a form of accountability.

- There is also public scrutiny and accountability. This form of scrutiny was, in particular, demonstrated in the case of the findings of Justice Hayne in the review of the Australian financial sector. ${ }^{4}$ No member of an authority wants to be publicly criticised for failing to properly discharge statutory tasks entrusted to them. The reputational risks are high.

- Finally, there is the political dimension. While I can say that appropriate boundaries of independence were observed throughout my term, it is still not lost on regulators that they are ultimately answerable to the democratic process. Such institutions are likely to rank loss of political confidence in them high on their risk registers.

As I recall, I further observed that we had a close working relationship with parallel agencies in Canberra, Ottawa, Washington and London, and that I struggled with the suggestion that their models of board governance were materially different to ours in the way that was being suggested.

3 The input methodologies decisions were subject to a range of process challenges over two years following the issuance of these decisions: see for example Vector Ltd v Commerce Commission [2012] NZSC 99, [2013] 2 NZLR 445. The merits review proceedings extended to 58 substantive challenges: see Wellington International Airport Ltd v Commerce Commission [2013] NZHC 3289.

4 Final Report: Royal Commission into Misconduct in the Banking, Superannuation and Financial Services Industry (Commonwealth of Australia, vol 1, 2019). 
This topic arose again from time to time during my tenure, including under the Harper review in Australia. ${ }^{5}$ No changes to the Australian Competition and Consumer Commission's (ACCC) governance structure were made following this review.

In more recent times a New Zealand Initiative (NZ Initiative) study suggested that the NZCC should adopt the governance model used by the Financial Markets Authority (FMA). ${ }^{6}$ They further appeared to assert that such an approach to governance accorded with the way that the relatively new United Kingdom Competition and Markets Authority (CMA) operates. In summary, their key recommendations included that: ${ }^{7}$

- Commissioner roles should be largely reshaped as governance roles (involving only two to four days per month) $;^{8}$ and

- $\quad$ substantial decision-making power should be delegated to the CEO.

These observations potentially point to two different governance models. The NZ Initiative model is the one tier board model. The political observation referred to above may be more suggestive of a further supervisory board model. ${ }^{9}$

The governance of competition law agencies is not a straightforward topic. It is one thing to talk about perceived ideal models of governance, based on corporate governance. It is quite another thing to understanding the workings of these institutions and how governance adjustments may impact. An appreciation of not only theory is required. The nature of the institution and the tasks it is required to perform, the subject matter under review and the pragmatic workings of these institutions are also relevant considerations.

I think it is informative to reflect on the following issues:

- Where does the NZCC stand in the context of international systems of governance for similar institutions?

- What are the implications for governance where the institution is obligated to perform extensive quasi-judicial decision-making tasks?

- What is the comparative nature of the subject matter?

5 Ian Harper and others Competition Policy Review: Final Report (Commonwealth of Australia, March 2015) [Harper review]

6 Roger Partridge and Amy Thomasson Who Guards the Guards? Regulatory Governance in New Zealand (The New Zealand Initiative, 2018).

7 At 79. It was also recommended that the skill set of Commissioners be broadened to include more members with industry experience.

8 At $52-53$.

9 For an outline of these two governance models see Annetje Ottow Market and Competition Authorities: Good Agency Principles (Oxford University Press, Oxford, 2015) at 108-109. 
- Conflicts of interest.

- Is there a better model?

\section{A International Systems of Governance}

In 2004 New York University Law School launched its Global Administrative Law project. This project was developed against the backdrop of globalisation, the shrinking of borders between countries and the rise of international systems of governance. This project extended to competition law agencies. A major work was published in 2013 which reviewed the antitrust law institutional frameworks of a wide range of jurisdictions, including New Zealand. ${ }^{10}$ This is perhaps the best survey of its kind.

The NZCC's current institutional design is not out of line with a multitude of other agencies. While there are variations between jurisdictions, most involve Commissioner roles along the lines followed in New Zealand. With reference to our closest agencies, we are a mirror image of the ACCC, and the Canadian Competition Bureau, the Federal Trade Commission and the Antitrust Division of the United States Department of Justice do not have board governance roles of the kind advocated above.

The position of the United Kingdom CMA is more complicated. This body is the product of a comparatively recent merger of two agencies: The Office of Fair Trade and the Competition Commission. I spent some time at the CMA during my tenure. They readily acknowledge the complexity of their institutional design. Further, not all decision-making rests under delegation with the CEO, as the NZ Initiative suggest. For example, two significant areas of carve out are Phase 2 mergers and market studies.

Mergers are considered in two phases. Phase 1 cases involving no obvious competition concerns are delegated. This is hardly surprising in a jurisdiction where there is a flood of applications under a mandatory notification regime. I expect the same approach would be adopted here, if we faced the same problem. Significantly, however, all merger cases involving some complexity progress to Phase 2 scrutiny for decision by a panel.

On my last visit to the CMA in 2018 I spent time discussing their approach to market studies, given that we were about to get these powers. The CMA is probably the leading international authority on market studies, and it is a significant part of their work. I was informed that all board members are fully involved in the substantive analysis of market studies, at every turn. Decisions here are made by the CMA board.

I should add that in my time on the NZCC I also had the opportunity to engage extensively with many other competition agencies from around the world, in particular from North America, Europe and South East Asia. Each year I participated in Organisation for Economic Co-operation and

10 Eleanor M Fox and Michael J Trebilcock (eds) The Design of Competition Law Institutions: Global Norms, Local Choices (Oxford University Press, Oxford, 2012). 
Development (OECD), International Competition Network (ICN) and related meetings which were attended by the 130 or so competition agencies which now exist around the world. There has, in fact, been a remarkable recent explosion in these numbers. ${ }^{11}$ Around 25 years ago New Zealand was one of only 30 or so countries which had such agencies. I am not aware that any of the leading competition law agencies have the kind of corporate governance model being advocated by the NZ Initiative.

It does not necessarily follow that, because everyone takes the same or a similar approach, this is right. But, conversely, is everyone wrong?

\section{B The Context of Quasi-Judicial Decision-Making}

Decision-making is a core part of the NZCC's functions. It is the tribunal of first instance that investigates and determines major matters across a range of subject areas including regulatory rulings, and clearance and authorisation applications. Market studies may be viewed as a parallel extension to this role.

The NZCC's role here is quasi-judicial. Its decisions are the first step in the legal process. I would estimate that such decision-making accounts for more than 60 per cent of Commissioner time. The imposition of such non-discretionary legislative demands clearly impacts on the institution's ability to engage in strategic planning. Strategies around enforcement priorities and education must be accommodated against these demands, because they cannot take precedence over the legislative dictate of adjudicative functions.

To provide some context of what the NZCC must adjudicate upon, consider the following five examples:

- Asset values and the Weighted Average Cost of Capital (WACC) for regulated entities. ${ }^{12}$

- Whether media plurality is a proper concern of competition law. ${ }^{13}$

- Whether a material increase in coordination was likely to occur as a result of Z Energy acquiring Caltex. ${ }^{14}$

- Whether vertical integration between Sky and Vodafone was likely to adversely impact on markets for mobile telephony and the roll out of fibre. ${ }^{15}$

11 See William E Kovacic "The United States and its Future Influence on Global Competition Policy" (2015) 22 Geo Mason L Rev 1157; and William E Kovacic and Marianela Lopez-Galdos "Lifecycles of Competition Systems: Explaining Variation in the Implementation of New Regimes" (2016) 79(4) LCP 85.

12 The Input Methodologies Decisions for Electricity Distribution Businesses, Gas Pipeline Businesses, Transpower and the Airports: NZCC Decisions 709-713 (20 December 2010).

13 NZME Ltd and Fairfax New Zealand Ltd [2017] NZCC 8.

14 Z Energy Ltd and Chevron New Zealand [2016] NZCC 10.

15 Vodafone Europe BV and Sky Network Television Ltd [2017] NZCC 1; and Sky Network Television Ltd and Vodafone New Zealand Ltd [2017] NZCC 2. 
- The retail fuel sector market study. ${ }^{16}$

These cases involved complex multi-disciplinary questions of law, economics and finance. They involved lengthy factual submissions and expert reports on the markets in question. At issue were speculative predictions and judgment calls about the future structure and functioning of markets.

Further, these cases often require the NZCC to rule in circumstances involving the disputed views of rivals and their experts. In a number of these cases the NZCC was also required to hold public conference hearings concerning disputed facts and opinions.

If Commissioners were to spend only two to four days a month on board matters when there are cases like these in play, which will invariably be the case, it is difficult to see that they could have meaningful involvement in or oversight of such cases. These are cases which pose complex and unique challenges.

It is predictable that the following kind of dialogue would arise under this model. Business would tell the board that the staff do not understand their business and that they got the decision wrong; the board would respond by saying that we have had insufficient exposure to the record to really know whether the decision was right or wrong.

During my time on the NZCC I witnessed the multi-disciplinary expertise that Commissioners brought to the decision-making process. I would have thought that this was self-evident. I find it somewhat perplexing that business is advocating to limit this involvement. Does business really want these decisions to be delegated to the CEO and staff in circumstances where effective Commissioner input will be essentially rendered redundant? In my view, business would likely be worse off under the $\mathrm{CEO} /$ staff delegation model being proposed by the NZ Initiative.

\section{Comparative Context and Subject Matter}

Should a "one size fits all" approach apply to governance for regulatory institutions? The current corporate governance model used by the FMA is said to be operating well. Is this reason to reshape the NZCC, as the NZ Initiative suggests? I should add that I do not have precise knowledge of the workings of the FMA's board, but I assume for present purposes that the NZ Initiative's portrayal of it is correct.

The ability of a board to delegate decision-making powers to a CEO depends in significant part on the subject matter, and the challenges faced by the institution. The FMA's tasks are, as I understand it, essentially based around the legal analysis and application of securities laws. For example, they license financial institutions and monitor the compliance of such institutions with disclosure requirements. The NZCC also has a small window of involvement in this field of securities regulation under its administration of the Credit Contracts and Consumer Finance Act 2003. Such tasks

16 Commerce Commission Market study into the retail fuel sector: final report (5 December 2019). 
essentially are confined to the analysis of legal rules, which can sometimes be complex, and the application of established facts to these rules. This is subject matter which is more capable of being delegated. Template considerations and processes can be used for assessment purposes.

I would characterise these kinds of challenges as being essentially legal, and based on retrospective factual analysis. The forward-looking predictive challenges facing the NZCC in respect of the structure and performance of markets seem to me quite different to the challenges which face securities regulators.

Against this background, there is, I suggest, no apparent logic in saying that the governance structure of one must necessarily apply to the other.

\section{$D$ Conflicts of Interest}

The adoption of the board model suggested by the NZ Initiative also runs into significant conflict of interest problems. The core membership of the boards of the NZCC, and the other competition agencies I have mentioned above, comprise lawyers and economists with expertise in the field. Their practices are based solely, or almost entirely, on work in the fields under scrutiny by the NZCC.

As I have already mentioned, much of the high-profile work of the NZCC involves contested positions between rivals. It would not be possible to recruit members for two to four days a month where, for the rest of their time, they would be involved in the continuation of their practices. This problem would also extend to the organisations to which they belong. The proposed new approach to governance would potentially exclude the lawyers and economists you would wish to attract to the NZCC.

\section{E Is There a Better Model?}

Textbook models of corporate governance do not necessarily point the way to the ideal structure for competition law agencies. There is no one simple or right approach. Competition and regulatory agencies function in environments with different political and historical backgrounds. In addition to the different functions and demands I have already outlined, these agencies also have different levels of baseline funding, and seek to attract human capital in different markets. All these factors variously impact on the approach to governance structures.

There may be a perception, with which I have some sympathy, that under the current structure Commissioners are heavily distracted with the burdens of their day to day demands. Are they best placed in these circumstances to provide the full suite of governance roles? Is there a better governance model that could apply to the NZCC?

I wonder if a hybrid board model may be worth some consideration. This model would involve the addition of (say) two new independent non-executive members to the existing board. The existing Commissioners would remain involved in the organisation's substantive decision-making and their other current governance roles. The involvement of the non-executive members would be part-time 
and targeted at strategic board meetings. They would critically review and challenge the direction of the institution through a fresh set of eyes.

This hybrid model is not novel. It was one of the options advanced in the draft Harper review in Australia, which suggested that the ACCC comprise full-time Commissioners and independent nonexecutive directors not involved in the day to day business of the agency. ${ }^{17}$ However, this option was not ultimately recommended in the final report.

This suggested hybrid model is also inspired in part by my perception of the role that Professor Bill Kovacic has played at the CMA. ${ }^{18}$ Professor Kovacic, along with another foreigner, Professor Annetje Ottow, ${ }^{19}$ were appointed as non-executive directors of the CMA at the time of its establishment. I expect that they have provided valuable independent oversight and challenges around the CMA board table.

Is this hybrid model ideal? Advocates of corporate governance models would likely say no. However, I suggest that this approach may go some way to address the tension in play here. It is a way to accommodate any perceived need for more independent board oversight, and not at the same time disturb the benefits of Commissioner input into substantive decision-making.

\section{POLICY CHALLENGES}

There is in my view a major policy issue which has largely gone under the radar which warrants some serious consideration.

In the course of the NZME/Fairfax hearing before the Court of Appeal we, and I expect the appellants, were taken by surprise at the Court's focus on total welfare and consumer welfare standards. This matter was not, in fact, directly before the Court in that appeal.

\section{A What the Court of Appeal said in NZME Ltd v Commerce Commission (NZME/Fairfax)}

To provide context, I begin with an outline of the key parts of the decision.

The Court's discussion of the topic began with an overview on the Act's objectives. ${ }^{20}$ The Court noted the two contrasting goals that have been the subject of endless debate in antitrust law. ${ }^{21}$

17 Competition Policy Review: Draft Report (Commonwealth of Australia, September 2014).

18 Professor Kovacic is the Global Competition Professor of Law and Policy at George Washington Law School and a former Chairman of the Federal Trade Commission.

19 Professor Ottow is former Dean of Law and now Vice President at Utrecht University.

20 NZME/Fairfax, above n 1, at [43]-[45].

21 At [43] and following. 
- There is the total welfare approach under which a transaction's benefits and detriments are valued equally regardless of who receives or incurs them. This approach excludes distributional considerations. Producers' surplus is treated as a welfare gain because the surplus is available for use elsewhere in the economy.

- The alternative goal is the consumer welfare approach. This introduces the notion that the gains achieved should be shared with consumers, because they will experience the anticompetitive impacts that may arise through increases in market power. Such distributive goals involve judgment calls, based on fairness.

The Court traced the NZCC's public benefits and authorisation guidelines over the years and observed that these favoured the total welfare approach, and that this approach was endorsed by the High Court in Air New Zealand v Commerce Commission (No 6). ${ }^{22}$

Next the Court traced the relevant legislative history, highlighting: ${ }^{23}$

- That in 1992 proposed legislation was not passed. This would have entrenched the total welfare standard, by requiring that efficiencies be the primary consideration in assessing public benefits and that distributional effects should be ignored.

- That in speaking to the Bill introducing the new purpose statement in s $1 \mathrm{~A}$ of the Act in $2001:^{24}$

- The Minister of the day said that this purpose statement makes clear that competition is "a means to promote the welfare of New Zealanders" and that "consumers are given special mention as they are the ultimate beneficiaries of competition". ${ }^{25}$ The language of his address is not without vagueness, but the Court probably introduced this citation to suggest it may have pointed more to the consumer welfare end of the spectrum.

- The Chairman of the Commerce Committee at the time was more direct. Noting the debate between the Chicago efficiency school and the so-called Harvard welfare based approach he concluded: "[t]his purpose statement makes it clear that the New Zealand Parliament supports a welfare based, Harvard School approach that puts the interests of consumers first." 26

22 Air New Zealand v Commerce Commission (No 6) (2004) 11 TCLR 347 (HC); and NZME/Fairfax, above n 1 , at [46]-[48] and [51].

23 At [48]-[50].

24 Commerce Amendment Bill 2001 (296-2).

25 (27 February 2001) 590 NZPD 7972, as cited in NZME/Fairfax, above n 1, at [49].

26 At [50]. 
There is next something of a sting in the tail of the Court's comments when it further reflected on this legislative history, and the practice followed under the NZCC's guidelines. ${ }^{27}$

- Firstly, the Court states that "[i]t is debateable whether the High Court should be taken to have held that the Commission must follow an objective that the Commission had adopted of its own volition and the Court did not itself evaluate against the legislative history". ${ }^{28} \mathrm{On}$ one, and perhaps the most obvious reading, this appears to be saying that, if the High Court had had proper regard to the legislative history, it should not have endorsed the total welfare approach taken in the NZCC's guidelines. ${ }^{29}$

- Secondly, the Court said that "this Court has never held that the Act compels a total welfare approach". 30

The Court further observed that "[t]he Australian Commission and Tribunal have not gone so far as the [New Zealand] Commission in the pursuit of total welfare". ${ }^{31}$ The Court observed that Australian case law supports the use of "a form of the total welfare standard" as the most appropriate standard for assessing public benefits. ${ }^{32}$ This form of total welfare standard involves distributive goals. While the Australian courts do not require that the efficiencies generated must necessarily be passed on to consumers, "it may be that, in some circumstances, gains that flow through only to a limited number of members in the community will carry less weight". ${ }^{33}$ There is little case law on the subject and I am not aware that any Australian case has in fact discounted benefits based on these distributional concerns.

Our Court of Appeal in NZME/Fairfax concluded that our legislation permits this Australian "modified total welfare approach". ${ }^{34}$ It further stated: "[w]e should not be taken to say, however, that the Commission must follow the modified total welfare approach in practice. The Commission is

27 At [52] and [53].

28 At [52].

29 Further doubt is cast by the Court of Appeal on earlier High Court decisions based on this approach of the Commission: see NZME/Fairfax, above n 1, at [62].

30 At [53].

31 At [66].

32 Qantas Airways Ltd [2005] ACompT 9, (2005) ATPR 42-065 at [185], as cited in NZME/Fairfax, above n 1, at [66].

33 Qantas Airways Ltd, above n 32, at [185], as cited in NZME/Fairfax, above n 1, at [66].

$34 N Z M E / F a i r f a x$, above $\mathrm{n} 1$, at [75]. 
equipped to develop policies and guidelines within the statutory framework, and it is responsible for doing so." 35

Predictably the NZCC has since this decision put out for consultation draft amendments to its Authorisation Guidelines which are along the following lines: there is a general rule that the total welfare standard will apply, with the modified total welfare approach being a potential exception to this rule. ${ }^{36}$ This guideline involves internally conflicting goals. The prevalent rule appears to be that the distribution of wealth is not relevant. But the NZCC is also retaining a discretion to modify this approach, and to discount benefits, where there may be questions about the distribution of the efficiency gains.

\section{B Problems with a Fused Total Welfare/Modified Total Welfare Approach}

\section{Rules with conflicting goals}

Problems arise where legislative provisions are open to conflicting interpretations. The general resolution to any such conflict or inconsistency is to prefer an approach based on the scheme and purpose of the legislation. ${ }^{37}$ However, such resolution here is further complicated because the conflict and inconsistency attaches not only to the application of the public benefit test under ss 58 and 67 , but also to the purpose statement itself under s $1 \mathrm{~A}$ of the Act. In such circumstances, the legislative history assumes importance as I will discuss further below.

The problem with the Australian rule formulation, which has persuaded the Court Appeal (and the NZCC), is that it walks into the troubled waters of the debate about the two conflicting schools of thought over the goals of antitrust, namely the total welfare and consumer welfare standards.

The total welfare standard is based on the premise that competition laws should promote allocative efficiency. The key advocates of this school of thought (Robert Bork, Richard Posner and others) view allocative efficiency to be an absolute goal. ${ }^{38}$ Allocative efficiency is indifferent as to the distribution of profits between producers and consumers.

The rival school of thought centres upon the consumer welfare model. The modern day recognition of this goal dates back to Robert Lande's influential work in the early 1980s which traced

35 At [75].

36 Commerce Commission Authorisation Guidelines (July 2019) at [83].

37 See Ross Carter Burrows and Carter Statute Law in New Zealand (5th ed, LexisNexis, Wellington, 2015) at ch 14 .

38 For an overview of these schools of thought see Mark N Berry "Efficiencies and Horizontal Mergers: In Search of a Defense" (1996) 33 San Diego L Rev 515 at 528-532. For an interesting historical survey of the subject see Barak Orbach "The Present New Antitrust Era" (2019) 60 Wm \& Mary L Rev 1439. 
with some precision the legislative history of antitrust laws (rather than economic theory). ${ }^{39}$ This school of thought holds that distributive goals do matter, and that competition laws should prevent the unfair acquisition of consumers' wealth by firms with market power. ${ }^{40}$

\section{The trade-off model and the problem with consumers' surplus}

A further problem with these alternate rule formulations is that they involve the application of an economic framework which accommodates only one of these rule formulations.

The Williamson model provides the recognised economic analysis for assessing the trade-off between efficiencies and market power. ${ }^{41}$ It works in the case of the total welfare standard because this model assumes that if the cost savings exceed the deadweight loss, the merger will result in a net efficiency gain (even though it permits firms to raise price above marginal cost). The model is, in fact, biased to produce this result because the cost savings are calculated over the entire output of the firm, while the deadweight loss is only spread over the reduction in output resulting from the predicted increase in price.

This model does not, however, work in the case of the consumer welfare standard because its application is dependent on the assumption that wealth transfers are "a matter of indifference" in circumstances where prices will increase, and output will be reduced. ${ }^{42}$ Attempts have been made to adapt the Williamson model to apply to the scenario where wealth transfers are taken into account, but without success.

Alan Fisher and Robert Lande, for example, explored the prospect that the trade-off requires that the cost savings outweigh both the deadweight loss and the consumers' surplus. ${ }^{43}$ But this will likely be unworkable because of the potential magnitude of consumers' surplus in any given case. They also explored, unsuccessfully, the possibility of a price standard where the efficiency gains may be thought to be sufficient to prevent price increases beyond current levels. Gary Roberts and Steven Salop later touched upon this same subject by suggesting an inquiry into whether consumers may better off where there are competitors who are in a position to "imitate" or "emulate" the advantages achieved by the

39 Robert H Lande "Wealth Transfers as the Original and Primary Concern of Antitrust: The Efficiency Interpretation Challenged" (1982) 34 Hastings LJ 65.

40 Before passing from this point I suggest that the Australian Tribunal's conclusion in Qantas Airways Ltd, above $\mathrm{n} 32$, at [185] that the "modified total welfare approach" should be viewed as "a form of the total welfare standard", is debatable. The modified total welfare standard involves a distribution assessment which, I suggest, places this standard closer to the consumer welfare standard than the total welfare standard.

41 Oliver E Williamson "Economies as an Antitrust Defense: The Welfare Tradeoffs" (1968) 58 AER 18.

42 At [27].

43 Alan A Fisher and Robert H Lande "Efficiency Considerations in Merger Enforcement" (1983) 71 CLR 1580 at 1631-1634. 
efficiency gains. ${ }^{44}$ There are obvious practical limitations in how this inquiry may unfold (including its time dimension). In any event, these price standard inquiries stray into the market power assessment. Satisfaction of them would be suggestive of no likely price increase, and no likely detriment as a result.

\section{The uncertainty of the discretion}

So where does this leave us? The proposed framework that either the total surplus or the consumer welfare standard may be applied in any given case is highly problematic. There are no guidelines as to when and how this election may be made by the NZCC and it is, I expect, unlikely that any such guidelines could meaningfully be developed.

Perhaps there could be an attempt to fashion further guidelines to articulate the circumstances where there may be concerns that the gains will only flow through to a limited number of members of the community. But this assumes that it can be predicted that the efficiency gains will be passed through to consumers. It has long been recognised that this prediction may be difficult to make. There may be significant practical difficulties in demonstrating that the efficiency gains will likely be passed through to consumers unless there is a competitive market, and market forces which would indicate that such pass through was likely. ${ }^{45}$ However, if such competitive forces are in play, then the competition concerns in question would have been unlikely to arise in the first place. The complexity of this pass-through issue should not be underestimated.

How might the NZCC's preference between the two standards be exercised in any given case? Who is going to win the battle? On this point, I share in passing the following observation made by Daniel Crane: ${ }^{46}$

One institutional explanation for the asymmetry of treatment [of merger generated efficiencies and merger generated social costs] is that the lawyer class in the antitrust agencies distrusts the economist class. As a class, economists (including many of the staff economists working in antitrust enforcement agencies) tend to support a total welfare standard for antitrust, believing that antitrust is a poor vehicle for addressing distributive concerns. By contrast, the lawyer class - reflecting the "consumer welfare" perspective of the courts and a moralistic concern about wealth redistribution and consumer rights-tends to prefer a consumer welfare standard.

44 The unpublished draft study of Professors Gary Roberts and Steven Salop is discussed in Joseph Kattan "Efficiencies and Merger Analysis" (1994) 62 Antitrust LJ 513 at 514 and 522-527.

45 See Robert Pitofsky "Proposals for Revised United States Merger Enforcement in a Global Economy" (1992) 81 Geo LJ 195 at 207-208. For further discussion of distributional issues relating to cost savings see Berry, above n 38, at 545-547.

46 Daniel A Crane "Rethinking Merger Efficiencies" (2011) 110 Mich L Rev 347 at 373 (footnotes omitted). 
This uncertainty as to the NZCC's preferred approach in any given case places advisers and their clients in an intractable position. Do you expend what will be vast resources developing a planned transaction and file for approval not knowing what approach will be taken? These cases will likely stand or fall on the quantum of likely productive efficiency gains. In the vast sea of measurement ambiguity, this is the one category in the efficiency equation that can be reasonably predicted, and authorisation cases are more or less won or lost on the accepted productive efficiency number. Presumably the NZCC could look to disturb this number in cases where there are concerns that the detriments are inappropriately overwhelmed by large productive efficiency numbers. When and how would this happen? This is the problem of the judgment call I have already alluded to.

A further uncertainty attaches to the litigious opponent. Even if the NZCC does not discount the benefits, and gives its approval to any given authorisation application, opponents with standing can challenge this decision through the appeal process. The Court of Appeal's decision in NZME/Fairfax will provide a respectable platform upon which to base any such challenge.

\section{The Way Forward}

I have raised problems rather than solutions. In truth, I do not think there is a solution short of waiting to see how the NZCC and the courts develop and apply the new thinking around the so-called "modified total welfare approach". However, these cases will be few and far between, and it will take too long for this "wait and see" approach to provide any kind of solution. Further, the current uncertainty may well impact on major transactions that may, as a consequence, be frustrated.

A detailed policy reassessment is needed. The issues which arise here are not confined to authorisation cases; they extend to the goals which lie at the heart of the legislation.

Policy development in New Zealand has, since the Act was passed in 1986, been the subject of sporadic episodes of legislative intervention. Is there a clearly discernible legislative history to guide us on the goals of the Act, and the application of the authorisation test? There are inevitably statements open to different interpretations by those of different persuasions. Further, the Court of Appeal's review of the legislative history in the NZME/Fairfax decision also reflects that other considerations to support the authorisation regime were in play back at the time the Act was passed. ${ }^{47}$ For example, harmonisation with Australian law and a recognition of the need for small market economies to sometimes tolerate high levels of concentration to overcome diseconomies of scale were relevant considerations in the background policy papers. ${ }^{48}$

47 NZME/Fairfax, above n 1, at [35]-[42].

48 See Department of Trade and Industry Commerce Bill 1985: A Background to the Bill and An Outline to its Provisions (August 1985); and Trade Practices Act Review Committee Report to the Minister for Business and Consumer Affairs (August 1976), as cited in NZME/Fairfax, above n 1, at [37], nn 38 and 40. 
While I have not had the opportunity to extensively revisit the legislative history dating back to the time the Act was passed, I expect that there is not a sufficiently clear legislative record upon which to make the reassessment that the Court of Appeal has called for in NZME/Fairfax. A policy reassessment of this issue is, in my view, desirable.

Apart from the challenges posed by the Court of Appeal's decision in NZME/Fairfax, the time for such a review is also right for another reason. There is at present a significant international debate around the goals of antitrust. Milton Handler once said "eternal verity cannot, in an ever-changing world, be ascribed to any one school". ${ }^{49}$ This observation resonates particularly to the current day. In his recent article "Antitrust and Democracy", Spencer Weber Waller observes: ${ }^{50}$

The debate over the goals of competition law has continued and strengthened in contemporary times.

Scholars both old and new argue for more than a thin diet of efficiency, defined as wealth maximization, as the animating principle of competition law. Economists from the University of Chicago have begun an annual conference to examine the negative effects of increased concentration in the economy. The media has increased coverage of issues of economic inequality and the abuse of power.

There is a vast recent international literature on the goals of antitrust. There has, particularly over the last decade, been a crescendo of support for the view that modernisation of antitrust is long overdue and that the refinement of the goals of antitrust should be part of this reassessment. While divergent views remain, ${ }^{51}$ much of the recent criticism has focused on the concept of consumer welfare being a source of confusion and controversy. The view has been expressed that this confusion has resulted in a technocratic approach to the application of antitrust laws which has supported a laissez-faire approach to antitrust enforcement. Resurgent fairness themes are advocated to address this perceived failure in enforcement. These fairness themes build on a range of ideas that condemn business size and profit seeking behaviour that becomes the source of undesirable distribution effects.

Fairness goals in this context can be variously described. However, to state these goals in fairness terms perhaps mischaracterises the substance of the debate. It is more refined than that. For example, Harry First and Spencer Weber Waller suggest that there should be a more democratic approach that reflects more the general political understandings and views of antitrust policy. ${ }^{52}$ They urge that courts should, for example, pay closer attention to the statutory purpose of the Sherman Act to protect

49 Milton Handler "Antitrust Exchange" (1991) 66 NYU L Rev 1257.

50 Spencer Weber Waller "Antitrust and Democracy" (2019) 46 Fla St U L Rev 807 at 812 (footnotes omitted).

51 See the papers presented at "The Goals of Antitrust Symposium" held at Fordham Law School in 2013. These papers appear in vol 81, issue 5 of the Fordham Law Review.

52 Harry First and Spencer Weber Waller "Antitrust's Democracy Deficit" (2013) 81 Fordham L Rev 2543 at 2572-2573. 
businesses from exclusionary conduct rather than to follow the economic theory du jour. ${ }^{53}$ Similar concerns based on legislative history are expressed in respect of mergers. They suggest that concentration should be viewed as an independent concern that Congress held at the time the Clayton Act was passed. ${ }^{54}$

Barak Orbach, another leading advocate for change, suggests that the goal of antitrust law should align with antitrust's core task, namely to protect the competitive process by banning business agreements, practices and transactions that unreasonably impact on the competitive process. ${ }^{55}$

This debate is, of course, taking place in the context of a different legislative history and fluctuating judicial preferences over the years. Nonetheless, there is much for us to observe and reflect upon from this debate. We also have the benefit of a jurisdiction which has a greater appetite to resolve this kind of dilemma through legislative reform. It is this appetite for reform which has the potential to provide the solution, as I have suggested above. This brings me to my next and final point.

I have, over the years, looked across the ditch with some envy at the Australian approach to policy assessments, to the extent that they have periodically set up wide ranging independent reviews of their trade practices legislation and the impact that this is having on their economy. The most recent of these independent committees of inquiry have been the Hilmer and Harper reviews in 1993 and $2015 .^{56}$

In an ideal world, such an approach to a review process in New Zealand would materially assist in providing a platform for an informed policy debate and legislative resolution of the problems I have highlighted tonight. These are not easy issues to address, and the benefit of bringing together a range of independent experts to address these issues is self-evident. Central questions which could be considered include:

- Has the total welfare standard served us well? I have on a number of occasions been challenged about the Cavalier Wool Holdings Ltd and New Zealand Wool Services International Ltd wool scour decision, ${ }^{57}$ and this may now provide a good case study for an

53 Sherman Antitrust Act of 189015 USC (US).

54 Clayton Antitrust Act of 191415 USC (US).

55 Barak Orbach "How Antitrust Lost its Goal" (2013) 81 Fordham L Rev 2253 at 2275-2276; and Barak Orbach The Consumer Welfare Controversy (Competition Policy International Antitrust Chronicle, November 2019) at 29 .

56 National Competition Policy Review (Australian Government Publishing Service, 1993) [Hilmer review]; and Harper review, above $\mathrm{n} 5$.

57 Cavalier Wool Holdings Ltd and New Zealand Wool Services International Ltd [2015] NZCC 31 (upheld on appeal in Godfrey Hirst NZ Ltd v Commerce Commission [2016] NZHC 1262; and Godfrey Hirst NZ Ltd v Commerce Commission [2016] NZCA 560). 
ex-post review. Have prices gone up and output been reduced? What has happened in respect of the rationalisation benefits? What alternate uses have come about?

- Which of the conflicting schools of thought is to be preferred?

- If the "modified total welfare approach" is to be preferred, what are the guidelines for its application?

- Should there be a more expansive rethink of the goals of the Act in New Zealand?

Above all, the review needs to be clear in its identification and articulation of the issues at hand. General statements open to multiple interpretations need to be avoided. Otherwise the uncertainty, and the debate, will simply continue into the future. 
